\title{
Effect on nitrogen losses from a sheep grazing system by the randomised distribution of excreta
}

\author{
$\underline{\text { M.J. Bell }}^{\text {a }}$, B.R. Cullen ${ }^{\text {a }}$ and R.J. Eckard ${ }^{\text {ab }}$ \\ ${ }^{a}$ Melbourne School of Land and Environment, University of Melbourne, Vic. 3010, Australia \\ ${ }^{b}$ Department of Primary Industries, 1301 Hazeldean Road, Ellinbank, Vic. 3820, Australia \\ Email: Matt.Bell@unimelb.edu.au
}

\begin{abstract}
Nitrogen excreted by ruminants in the form of dung and urine posses a potential source of pollution. The aim of this work was to assess the effect on the amount of nitrogen (N) that is lost from a sheep grazing system by leaching, volatilisation and denitrification when excreta is randomly rather than uniformly distributed over an area. The single heterogeneous paddock (SHP) option within the dynamic biophysical model EcoMod was used to allocate excreta to a grazed one hectare area. The SHP approach allows a paddock's soil nutrients, pasture production and species composition to be simulated independently within defined areas.
\end{abstract}

Simulations used climate data for a 100 year period from the Ellinbank Research Farm in south-eastern Victoria, which has a temperate climate and Red Mesotrophic Haplic Ferrosol soil type. The pasture was perennial ryegrass (Lolium perenne)/white clover (Trifolium repens), which was grazed every 60 days by $45 \mathrm{~kg}$ wethers (maintaining their liveweight). The average annual amount of $\mathrm{N}$ lost by leaching, volatisation or denitrification $(\mathrm{kg} \mathrm{N} / \mathrm{ha}$ ) and their total amount per $\mathrm{kg} \mathrm{N}$ applied and fixed by legumes were estimated for the most recent 40 years. It was assumed that one animal would produce $0.5 \mathrm{~m}^{2}$ of excreta each grazing day. Therefore, for a range of stocking densities from 200 to 2000 sheep/ha, excreta were allocated either uniformly to the whole 1 ha paddock or randomly to 1 to $10 \%$ of the grazed area (representing 200 to 2000 sheep/ha). The range of stocking densities was used to represent an increasing amount of excreta being applied within the grazing system.

The model estimated that the average annual $\mathrm{N}$ losses from the system ranged from 91 to $67 \mathrm{~kg} \mathrm{~N} / \mathrm{ha}$ and 92 to $95 \mathrm{~kg} \mathrm{~N} /$ ha from leaching, 3 to $21 \mathrm{~kg} \mathrm{~N} / \mathrm{ha}$ and 3 to $19 \mathrm{~kg} \mathrm{~N} /$ ha from volatilisation, $5 \mathrm{~kg} \mathrm{~N} / \mathrm{ha}$ and 5 to $4 \mathrm{~kg}$ $\mathrm{N} /$ ha from denitrification for low to high stocking densities for uniform and randomly distributed excreta respectively. This study showed that the random distribution of excreta significantly influences the annual $\mathrm{N}$ losses through leaching and denitrification from a grazing system. When the excreta from 1200 or more sheep/ha was distributed to $7 \%$ or more of the grazed area, the proportion of total $\mathrm{N}$ losses per year were on average significantly higher when excreta was distributed randomly compared to uniformly. Further development of the SHP approach to enable the random allocation of excreta in grazing systems with low stocking densities rather than 'mob' stocking would allow models to better apportion $\mathrm{N}$ losses, even though annual $\mathrm{N}$ losses may not be significantly different too if excreta was assumed to be uniformly distributed.

Keywords: Excreta, modelling, distribution, nitrogen losses, grazing system 


\section{INTRODUCTION}

Nutrients are lost from pasture systems largely through the actions of the grazing animal. The amount of nitrogen $(\mathrm{N})$ returned to the soil of a grazing system directly (via microbial mineralisation, nitrification or denitrification processes) or indirectly (via runoff, leaching and volatilisation) poses a potential source of ground water nitrate pollution or nitrous oxide $\left(\mathrm{N}_{2} \mathrm{O}\right)$ emissions to the atmosphere (de Klein and Eckard, 2008). A large proportion of the $\mathrm{N}_{2} \mathrm{O}$ emissions from agriculture in Australia are derived from animal excreta (26\% or $3.9 \mathrm{Mt} \mathrm{CO}_{2} \mathrm{e}$ ) (DCC, 2009). The $\mathrm{N}$ inputs to the grazing system (influencing nitrate availability) and the soil's water-filled pore space, with soil temperature to a lesser extent, were identified as key factors affecting $\mathrm{N}_{2} \mathrm{O}$ production (de Klein and Eckard, 2008). The loss of a nutrient such as $\mathrm{N}$ typically occurs from stock camps (Haynes and Williams, 1993). The amount of $\mathrm{N}$ excreted in dung and urine (excreta) represents inefficiency in feed $\mathrm{N}$ use by the animal. Due to the distribution of nutrients in excreta being in concentrated areas, there is potential for the quantities of nutrients supplied to be greater than the short-term requirements of the pasture plants in the area. This is exacerbated by clustering and overlays of excreta for a given area (Morton and Baird, 1990; Pleasants et al., 2007).

The grazing area covered by excreta depends on the amount deposited, which is influenced by the number of animals, the quantity produced per animal and its concentration. The concentration of $\mathrm{N}$ in dung has been found to remain relatively constant regardless of diet $\left(0.8 \mathrm{~g} \mathrm{~N} 100 \mathrm{~g}^{-1} \mathrm{DM}\right.$ consumed), whereas the $\mathrm{N}$ content of urine increases as dietary $\mathrm{N}$ increases beyond animal requirements (Haynes and Williams, 1993). Even though the area of an individual dung and urine patch is difficult to estimate, it is reasonable to assume that in sheep that a dung and urine patch can be produced about 20 times per day with an approximate area of 0.025 $\mathrm{m}^{2}$ (Morton and Baird, 1990). In comparison, cattle defecate about 10 times per day with an average patch area of about 0.05 and $0.2 \mathrm{~m}^{2}$ for dung and urine respectively (Haynes and Williams, 1993). The grazing area affected by excreta is not only a function of the type of livestock being carried by the pasture but also their stocking density. A biophysical and mechanistic model such as EcoMod (Johnson et al., 2008) can help simulate a grazing animal, climate and soil properties of a whole farm system. The spatial and temporal variability in the $\mathrm{N}$ balance can be modelled on a daily time-step. The EcoMod model has been previously used to simulate $\mathrm{N}$ losses at a range of sites with different climates and soil types (Lodge and Johnson, 2008; Snow et al., 2009; Eckard and Cullen, 2011). The single heterogeneous paddock (SHP) approach within EcoMod can help model the processes within the whole farm system that have a direct or indirect relationship to the concentration of $\mathrm{N}$ in excreta (Snow et al., 2009; Eckard and Cullen, 2011). Snow et al. (2009) discussed the need to study the impact of the non-uniform distribution of $\mathrm{N}$ excreta on not only leaching losses, but also volatilisation and denitrification losses under a managed grazing system.

This study uses an existing pasture model to investigate the effect on the amount of $\mathrm{N}$ that is lost from a sheep grazing system by leaching, volatilisation and denitrification when excreta is randomly rather than uniformly distributed. Suggestions are made of further developments to the model to better represent $\mathrm{N}$ losses from a grazing system.

\section{MATERIALS AND METHODS}

\subsection{Pasture model and site simulated}

The single heterogeneous paddock (SHP) option within the dynamic biophysical model EcoMod (Johnson et al., 2008) was used to allocate excreta (dung and urine together) to a grazed one hectare area. The SHP approach allows a paddock's soil nutrients, pasture production and species composition to be simulated independently within a defined proportion of the grazed area on a daily time-step. This model incorporates daily climate data, soil properties, pasture species, livestock and management to describe the whole farm system. The climate data inputs include minimum and maximum temperature $\left({ }^{\circ} \mathrm{C}\right)$, rainfall $(\mathrm{mm})$, solar radiation $\left(\mathrm{MJ} / \mathrm{m}^{2}\right)$, vapour pressure $(\mathrm{kPa})$ and minimum and maximum relative humidity $(\%)$. The climate data were obtained from the SILO database (Jeffery et al., 2001).

Simulations were based on climate data from the years 1901 to 2000 for the Ellinbank Research Farm in south-eastern Victoria $\left(-38.25^{\circ} \mathrm{N}, 145.93^{\circ} \mathrm{E}\right)$. Ellinbank has a temperate climate (average daily minimum and maximum temperatures of 8.6 and $18.4^{\circ} \mathrm{C}$ respectively) and a mean annual rainfall $1054 \mathrm{~mm}$ during the study period. The soil type was a Red Mesotrophic Haplic Ferrosol (Isbell 1996). The pasture system was a dryland (i.e. rainfed) perennial ryegrass (Lolium perenne)/white clover (Trifolium repens) sward, which was grazed for a period of one day every 60 days ( 6 or 7 grazings per year) by $45 \mathrm{~kg}$ wethers (maintaining their liveweight). The model assumed that $15 \%$ of the consumed $\mathrm{N}$ was removed by the animal and not defecated. 
Bell et al., Effect on grazing system nitrogen losses by the randomised distribution of excreta

The proportion of $\mathrm{N}$ excreted in dung $\left(\varphi_{\mathrm{F}}\right)$ depends on the N-energy density $\left(\rho_{\mathrm{I}}\right)$ of feed intake $(\mathrm{kg} \mathrm{N} / \mathrm{MJ})$ and the proportion of $\mathrm{N}$ intake that is excreted $\left(\lambda_{\mathrm{N}}\right)$ :

$\varphi_{\mathrm{F}}=\beta+(\alpha-\beta) \exp \left(-\gamma \rho_{\mathrm{I}} \lambda_{\mathrm{N}}^{2}\right)$

where $\alpha$ and $\beta$ were assumed to be 45 and $13 \%$ for values of $\varphi_{\mathrm{F}}$ at very low and very high $\lambda_{\mathrm{N}}$ respectively, and $\gamma$ is an empirical coefficient, which was assumed to be $560 \mathrm{MJ} / \mathrm{kg}$ N. No supplementary feed was fed to the sheep, which meant the $\mathrm{N}$ inputs to the system were from excreta or fixation by legumes. It was assumed that one animal would produce $0.5 \mathrm{~m}^{2}$ of excreta each grazing day $\left(20\right.$ deposits of $\left.0.025 \mathrm{~m}^{2}\right)$.

A range of stocking densities from 200 to 2000 sheep/ha were used to allocate an increasing amount of $\mathrm{N}$ excreta over an increasing proportion of a 1 ha paddock on each grazing day. The sheep grazed the same paddock every 60 days to allow the pasture biomass time to recover from grazing and so that allocation of excreta was compared on the same days. Excreta were applied to the grazed area either:

- Uniformly to the whole 1 ha paddock; or

- Randomly over 1 to $10 \%$ of the grazed area per day representing 200 to 2000 sheep/ha (increasing in 200 sheep/ha intervals).

\subsection{Nitrogen predictions}

Annual average N predictions for the 40 years from 1961 to 2000 were used for the analysis. The simulations were run for 100 years from 1901 to 2000 to allow for full expression of the nitrogen balance and its variability. The average annual $\mathrm{N}$ inputs $(\mathrm{kg} \mathrm{N} / \mathrm{ha})$ to the grazing system by excreta and fixation by legumes were predicted. The amount of $\mathrm{N}$ fixed by legumes was dependent on the proportion of legumes in the grazing sward. The model does not explicitly predict nitrogen losses from nitrification or runoff. The main sources of $\mathrm{N}$ lost $(\mathrm{kg} \mathrm{N} / \mathrm{ha})$ from the system are by leaching of nitrate, ammonia volatisation from urine and denitrification producing nitrous oxide $\left(\mathrm{N}_{2} \mathrm{O}\right)$ and gaseous nitrogen $\left(\mathrm{N}_{2}\right)$.

Volatilisation $\mathrm{N}$ losses from urine were influenced by temperature and rainfall, whereby:

- $\quad$ Volatilisation $=0.20 \times \mathrm{kg}$ urine $\mathrm{N} \times$ temperature ${ }^{\circ} \mathrm{C} / 20$; and

- Rainfall $>5 \mathrm{~mm}$ stopped volatilisation.

Denitrification $\mathrm{N}$ losses were indirectly related to the excreta inputs as a result of an increase in soil nitrate. Temperature, water-filled pore space (WFPS) and soil carbon status influence the rate of denitrification, using the same generic response functions as for other soil processes. Denitrification was predicted based on the model of Granli and Bøckman (1994) by:

- The onsets of $\mathrm{N}_{2} \mathrm{O}$ and $\mathrm{N}_{2}$ losses were at 0.6 and 0.8 saturation of the WFPS and cessation of $\mathrm{N}_{2} \mathrm{O}$ loss at 0.95 saturation of the WFPS; and

- The maximum rate of denitrification was $0.25 \mathrm{mg} \mathrm{N} / \mathrm{kg}$ soil.

It was assumed that the optimum $\mathrm{N}$ content for photosynthesis was 4 and $4.5 \%$ for perennial ryegrass and white clover respectively.

\subsection{Data analysis}

The Mann-Whitney U-Test was used to evaluate any significant difference $(P<0.05)$ in total $\mathrm{N}$ intake, total $\mathrm{N}$ inputs, total $\mathrm{N}$ losses, leaching, volatilisation and denitrification $\mathrm{N}$ losses for an increasing amount of excreta distributed randomly or uniformly to the grazed area.

\section{RESULTS}

\subsection{Total nitrogen inputs and losses from the grazing system}

The average annual pasture intakes were similar at stocking rates of 200 sheep/ha when excreta was distributed uniformly and randomly (both $0.9 \pm 0.1 \mathrm{t} \mathrm{DM} /$ ha; mean \pm s.d.), but were higher for a uniform rather than random distribution when animals were more densely stocked $(6.4 \pm 0.8$ and $5.8 \pm 0.8 \mathrm{t} \mathrm{DM} / \mathrm{ha}$ at 
2000 sheep/ha respectively). Given that on average pasture was 4\% N, at a stocking density of 1200 to 2000 sheep/ha, the uniform distribution resulted in a higher $\mathrm{N}$ intake/ha compared to that distributed randomly $(209 \pm 18$ to $274 \pm 33 \mathrm{t} \mathrm{DM} /$ ha and $202 \pm 19$ to $247 \pm 31 \mathrm{t} \mathrm{DM} /$ ha respectively; $\mathrm{U}=646$ to 488 , all $P<0.05)$. However, total $\mathrm{N}$ inputs to the grazing system were not significantly different between the two methods for allocating excreta (Figure 1), due to $\mathrm{N}$ fixation by legumes. Under the conditions in this study, $\mathrm{N}$ fixation by legumes made up $72 \%$ of $\mathrm{N}$ inputs when the stock density was 200 sheep/ha for uniform and random allocations, compared to 29 and $36 \%$ at 2000 sheep/ha, respectively.
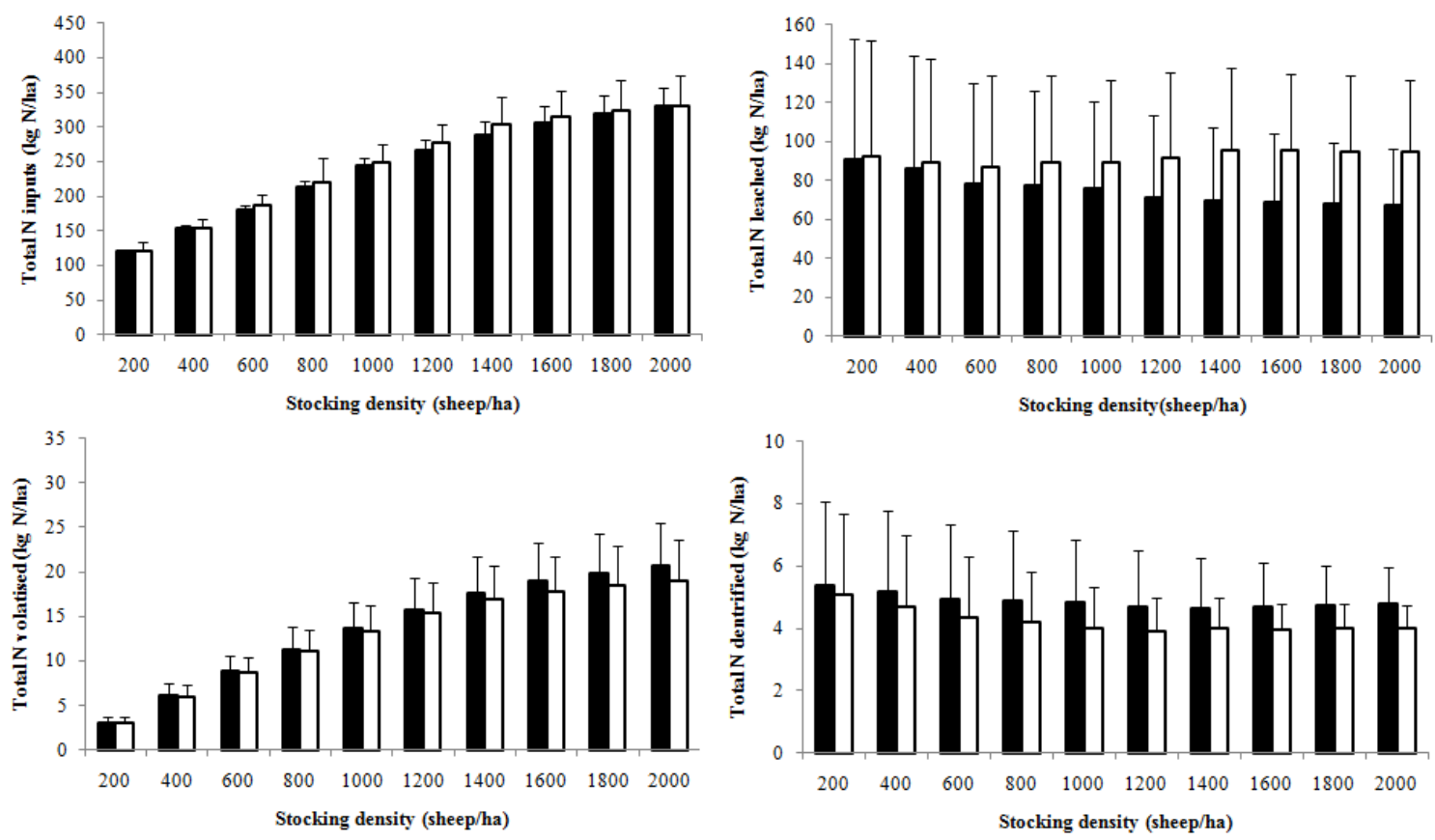

Figure 1. Mean annual nitrogen $(\mathrm{N})$ inputs, and $\mathrm{N}$ leached, volatilised or denitrified when excreta from 200 to 2000 sheep/ha was distributed uniformly ( $\mathbf{a})$ or randomly ( $\square$ ) to the grazed area.

Figure 1 shows that the average annual $\mathrm{N}$ leaching losses from the system ranged from $91 \pm 62$ to $67 \pm 29 \mathrm{~kg}$ $\mathrm{N} /$ ha and $92 \pm 60$ to $95 \pm 37 \mathrm{~kg} \mathrm{~N} /$ ha for low to high stocking densities and uniform and randomly distributed excreta respectively. Volatilisation $\mathrm{N}$ losses ranged from $3.1 \pm 0.7$ to $21 \pm 4.7 \mathrm{~kg} \mathrm{~N} / \mathrm{ha}$ and $3.1 \pm 0.7$ to $19 \pm$ $4.7 \mathrm{~kg} \mathrm{~N} / \mathrm{ha}$ for low to high stocking densities and uniform and randomly distributed excreta respectively. Whereas, denitrification losses were $5.4 \pm 2.7$ to $4.8 \pm 1.2 \mathrm{~kg} \mathrm{~N} / \mathrm{ha}$ and $5.1 \pm 2.6$ to 4.0 to $0.7 \mathrm{~kg} \mathrm{~N} / \mathrm{ha}$ for low to high stocking densities and uniform and randomly distributed excreta respectively. On average, the N/ha lost by leaching remained at a similar level when excreta was distributed randomly to 1 to $10 \%$ of the grazed area but gradually reduced for the uniformly distributed excreta. Volatilisation $\mathrm{N}$ losses increased with an increasing area of the grazing receiving excreta, and denitrification losses showed a similar pattern to leaching, however for both volatilisation and denitrification the losses were higher when excreta was distributed uniformly rather than randomly at higher stocking densities.

\subsection{Proportion of nitrogen inputs lost from the grazing system}

Distributing excreta over a larger proportion of the grazed area reduced the proportion of total $\mathrm{N}$ inputs lost by leaching and denitrification (Figure 2). With $\mathrm{N}$ excreta from 1400 to 2000 sheep/ha was randomly allocated, total $\mathrm{N}$ losses were significantly greater than when excreta was uniformly distributed $(\mathrm{U}=603$ to $475, P<0.05$ to $P<0.001)$. Leaching was the main source for $\mathrm{N}$ loss at 74 and $75 \%$ of $\mathrm{N}$ inputs at 200 sheep/ha to 21 and $29 \%$ at 2000 sheep/ha for uniform and random distributions of excreta respectively. In comparison, Figure 2 shows that the proportion of $\mathrm{N}$ inputs lost by volatilisation ranged from 3 to $6 \%$ and 4 to $1 \%$ for denitrification losses across the range of stocking densities. The random distribution of excreta significantly $(P<0.05)$ influenced the loss of $\mathrm{N}$ by leaching and denitrification from a grazing system but not volatilisation (Figure 2). The average annual $\mathrm{N}$ leaching losses when excreta from 1400 to 2000 sheep/ha was 
distributed randomly was significantly greater than when distributed uniformly ( $\mathrm{U}=564$ to $452, P<0.01$ to $P<0.001$ ), as was the case for total $\mathrm{N}$ losses as mentioned above. Average annual denitrification $\mathrm{N}$ losses became significantly greater when excreta from 1200 to 2000 sheep/ha was distributed uniformly rather than randomly to the grazed area $(\mathrm{U}=619$ to $538, P<0.05$ to $P<0.01)$.
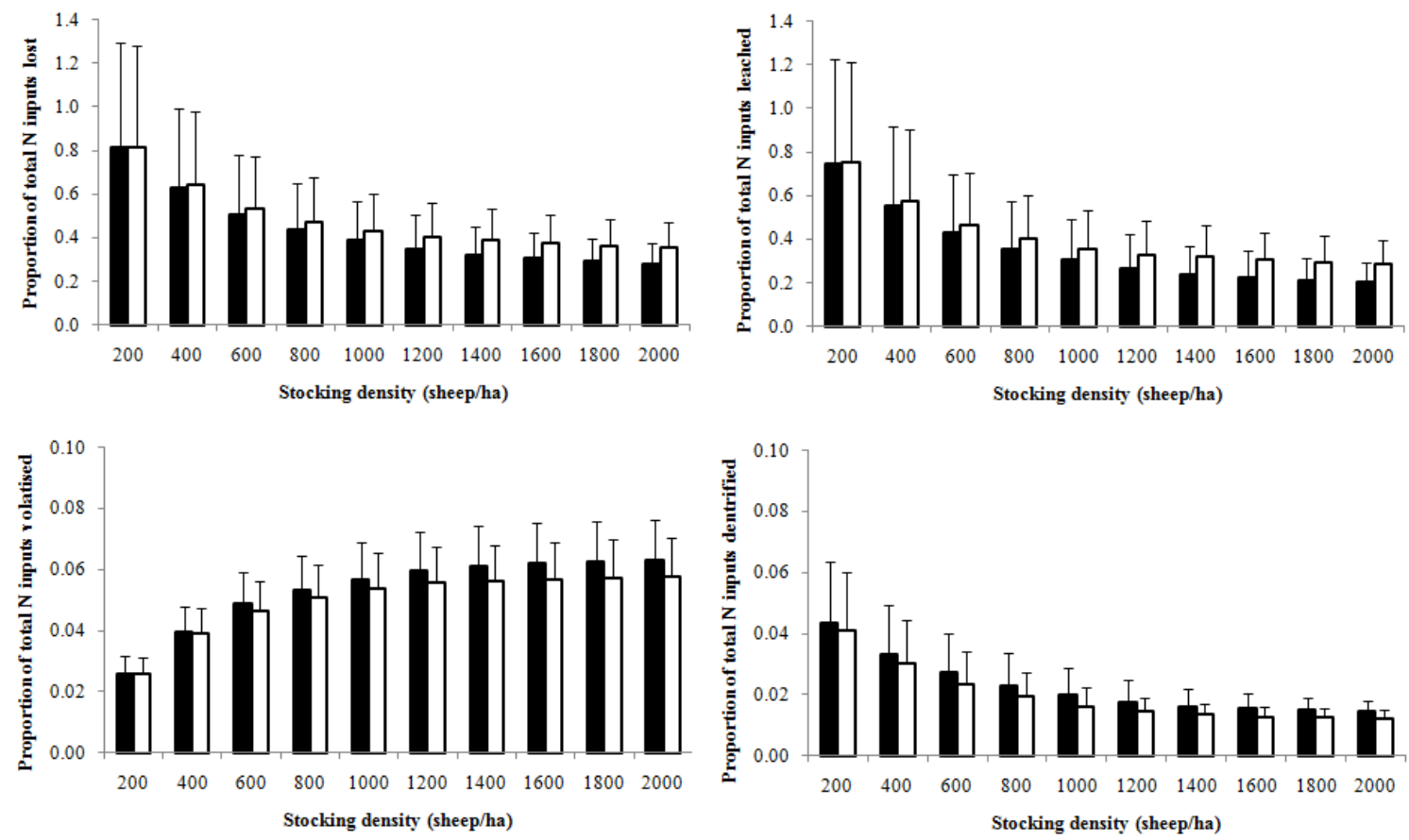

Figure 2. Proportion of total nitrogen $(\mathrm{N})$ inputs that were lost from the system, leached, volatilised or denitrified when excreta from 200 to 2000 sheep/ha was distributed uniformly ( $\square$ ) or randomly ( $\square$ ) to the grazed area.

\section{DISCUSSION AND CONCLUSIONS}

This study showed that the distribution of excreta to a grazed area not only influences the proportion of $\mathrm{N}$ inputs leached from the soil (Snow et al., 2009) but also the proportion of $\mathrm{N}$ inputs lost via denitrification. As expected, the uniform distribution of $\mathrm{N}$ to a larger proportion of grazing promotes better plant utilisation and growth, with higher animal $\mathrm{N}$ intakes and potentially less $\mathrm{N}$ leaching than if randomly allocated, even at a high stocking rate. Naturally, however, nitrogen excreted by grazing animals is distributed randomly in clusters and concentrated in small areas (Morton and Baird, 1990). The random allocation and potential overlap of $\mathrm{N}$ returned can lead to a higher concentration of nutrients in a given area and increased risk of leaching, which was the main source of $\mathrm{N}$ loss from this grazing system. Even though $\mathrm{N}$ losses by denitrification were relatively small (between 1 to $4 \%$ of $\mathrm{N}$ inputs), randomly distributing excreta significantly reduced denitrification losses at higher stocking densities (1200 sheep/ha or more) due to the constraint on the rate of denitrification per $\mathrm{kg}$ soil. However, this surplus $\mathrm{N}$ can then be leached from the soil. There was no significant effect on volatilisation $\mathrm{N}$ losses but a slight trend towards a higher proportion of total $\mathrm{N}$ inputs being lost at higher stocking densities, due to temperature and rainfall effects on urine $\mathrm{N}$.

As discussed by Snow et al. (2009), it is a weakness of pastoral simulation models to ignore that grazing ruminants return the nutrients in their excreta in patches within the grazed area rather than evenly. This does add complexity to the model, but the distribution of excreta to pasture can significantly influence pasture growth and prediction of $\mathrm{N}$ losses from different sources within the system across a range of stocking rates. Within a year, a dynamic modelling approach is required to simulate the $\mathrm{N}$ processes within a grazing system and its nutrient losses (Snow et al., 2009). A negative binomial distribution has been found to be the most suitable model to describe the distribution of excreta, as it incorporates overlap and clustering of deposits (Petersen et al., 1956; Morton and Baird, 1990). This approach includes a Poisson Index function that allows for a change in clustering with stocking density. Morton and Baird (1990) found that the Poisson Index tended to decrease with increasing stocking density. This approach would better represent the clustering of 
excreta under different stocking densities than in clustering compared to a more randomised distribution of excreta available in EcoMod. A limitation of the SHP in EcoMod is its ability to simulate nutrient allocation to smaller areas of the grazing, which would be more representative of camping effects under stocking densities of less than 200 sheep/ha rather than 'mob' stocking levels. Even at what would be considered a high stocking density in southern Australia of 200 sheep/ha, this study showed that there was no significant difference in total annual $\mathrm{N}$ inputs, $\mathrm{N}$ intake, $\mathrm{N}$ losses by leaching, volatilisation and denitrification between the uniform and random allocation of excreta. In this study, a uniform distribution of excreta would have been adequate to simulate annual $\mathrm{N}$ fluxes within the grazing system with 1000 or less sheep/ha, but not individual $\mathrm{N}$ loss processes over a range of stocking densities.

In conclusion, the SHP option in the EcoMod model can help simulate the dynamic $\mathrm{N}$ fluxes within a grazing system. Further development of the SHP approach to enable the random allocation of excreta in grazing systems with low stocking densities would allow better representation of $\mathrm{N}$ losses across a range of systems, even though annual $\mathrm{N}$ losses may not be significantly different to if excreta was assumed to be uniformly distributed.

\section{ACKNOWLEDGMENTS}

This work was supported by funding from Dairy Australia, Meat and Livestock Australia and the Australian Government Department of Agriculture, Fisheries and Forestry under its Australia's Farming Future Climate Change Research Program.

\section{REFERENCES}

DCC (Department of Climate Change), (2009). National Inventory Report 2007 - Volume 1. The Australian Government Submission to the UN Framework Convention on Climate Change, GPO Box 854, Canberra, ACT 2601, p. 217.

de Klein, C.A.M. and Eckard, R.J. (2008). Targeted technologies for nitrous oxide abatement from animal agriculture. Australian Journal of Agricultural Research, 48, 14-20.

Eckard, R.J. and Cullen, B.R. (2011). Impacts of future climate scenarios on $\mathrm{N}_{2} \mathrm{O}$ emissions from pasturebased dairy systems in SE Australia. Animal Feed Science and Technology, 166:736-748.

Granli, T., Bøckman, O.C., 1994. Nitrous oxide from agriculture. Norwegian Journal of Agricultural Sciences Supplement, 12, 7-128.

Haynes, R.J., Williams, P.H., 1993. Nutrient cycling and soil fertility in the grazed pasture ecosystem. Advances in Agronomy, 49, 119-199.

Isbell, R.F. (1996). Australian soil and land survey handbook: the Australian soil classification. CSIRO Publishing: Collingwood, Vic.

Jeffrey, S.J., Carter, J.O., Moodie, K.M. and Beswick, A.R. (2001). Using spatial interpolation to construct a comprehensive archive of Australian climate data. Environmental Modelling \& Software, 16, 309-330.

Johnson, I.R., Chapman, D.F., Snow, V.O., Eckard, R.J., Parsons, A.J., Lambert, M.G. and Cullen, B.R. (2008). DairyMod and EcoMod: Biophysical pastoral simulation models for Australia and New Zealand. Australian Journal of Agricultural Research, 48, 621-631.

Lodge, G.M. and Johnson, I.R. (2008). Agricultural drought analyses for temperate Australia using a biophysical pasture model. 1. Identifying and characterising drought periods. Australian Journal of Agricultural Research, 59, 1049-1060.

Morton, J.D. and Baird, D.B. (1990). Spatial distribution of dung patches under sheep grazing. New Zealand Journal of Agricultural Research, 33, 285-294.

Petersen, R.G., Lucas, H.L. and Woodhouse, W.W. (1956). The distribution of excreta by freely grazing cattle and its effects on pasture fertility. I. Excretal distribution. Agronomy Journal, 48, 440-444.

Pleasants, A.B., Shorten, P.R. and Wake, G.C. (2007). The distribution of urine deposited on a pasture from grazing animals. Journal of Agricultural Science, 145, 81-86.

Snow, V.O., Johnson, I.R. and Parsons, A.J. (2009). The single heterogeneous paddock approach to modelling the effects of urine patches on production and leaching in grazed pastures. Crop \& Pasture Science, 60, 691-696. 